\title{
A ESCRITURA PICTURAL DE AleJANDRo XUl SOLAR ${ }^{1}$
}

Yara Augusto

Doutoranda em Literatura Comparada do Programa de Pós-graduação em Estudos Literários / UFMG (bolsista CAPES)

\begin{abstract}
RESUMO
Este estudo investiga o diálogo que se estabelece entre as artes do texto e da imagem, a partir do processo progressivo de inserção da escritura na obra pictórica do artista argentino Alejandro Xul Solar (1887-1963).
\end{abstract}

\section{PALAVRAS-CHAVE}

Escritura, pintura, poesia visual, estudos intersemióticos

"Pintor, escribidor y pocas cosas más."2

"Do passado caligráfico que me vejo obrigado a lhes supor, as palavras conservaram sua derivação do desenho e seu estado de coisa desenhada: de modo que devo lê-las superpostas a si próprias; são palavras desenhando palavras. (...) Texto em imagem.”3

Autor de uma das obras mais significativas e intrincadas da modernidade argentina e da arte latino-americana do século 20, Alejandro Xul Solar (1887-1963) foi um criador inveterado, interessado por diversos campos artísticos, disciplinas e mecanismos de significação. No interstício entre as artes, desenvolveu uma instigante produção criativa, que investiga as potencialidades expressivas inerentes à aproximação entre distintos sistemas semióticos. Nascido na Argentina e filho de imigrantes, de origem materna italiana e paterna

\footnotetext{
${ }^{1}$ Este estudo apresenta a discussão de alguns dos resultados de pesquisa obtidos na dissertação de mestrado Por uma escritura pictural: texto e imagem na arte de Alejandro Xul Solar (2011), orientada pela Professora Vera Casa Nova, no âmbito do Programa de Pós-Graduação em Letras: Estudos Literários da FALE/UFMG.

${ }^{2}$ XUL SOLAR. Autómatas en la história chica, p. 132.

${ }^{3}$ FOUCAULT. Isto não é um cachimbo, p. 25.
} 
alemã, Xul Solar vivenciou a soma de culturas e tradições distintas que se inscreviam no país, durante o vertiginoso processo de modernização. Essa condição de artista formado em uma cultura de mescla ${ }^{4}$, expressão cunhada por Beatriz Sarlo para definir a cultura argentina, tensionada entre as aspirações de modernidade e vanguarda europeias e os vestígios da cultura rural criolla, conflui em uma produção criativa diversificada, concebida a partir de uma grande variedade de estilos, técnicas e campos artísticos, bem como na elaboração das obras de caráter híbrido, de natureza intersemiótica, por ele executadas.

Na Europa do início do século 20, destino de jovens artistas e intelectuais latinoamericanos que desejavam complementar a própria formação, Xul Solar estabelece contato com as vanguardas e suas inovadoras propostas e técnicas artísticas. Ao retornar a seu país de origem, no contexto de discussão de questões relativas à identidade e à dependência cultural, vigente na efervescente Buenos Aires da década de 1920, que vivenciava as perdas e os ganhos do processo de modernização da cidade, a emergência dos movimentos locais de vanguarda estética e a heterogeneidade cultural e discursiva propiciada pela massiva imigração, Xul Solar se entusiasma com a pretensão de recriar toda uma tradição por um viés moderno, com o objetivo de estabelecer uma nova arte. Movido pelo ímpeto de renovação artística, ele formula o neocriollo, língua artificial de aspiração utópica, composta, inicialmente, por vocábulos do espanhol, português e inglês, e criada com a intenção de expressar toda sorte de significados. Concebido como uma língua auxiliar para a América Latina, o neocriollo compôs parte de uma proposta artística panamericanista, orientada em torno de textos e imagens, que visava a promover a arte e a cultura latino-americanas, de modo a que pudessem fazer frente à produção criativa europeia. Em seu gosto pelo manejo de significantes, Xul Solar desenvolve, posteriormente, a panlingua, idioma de pretensões universais, cujo insólito dicionário consiste no jogo de xadrez pansemiótico Panajedrez (1945), assim como um conjunto de sistemas gráficos de linguagem a serem utilizados em sua pintura. Diante disso, faz-se manifesto que ele investe em um intenso e fecundo trabalho com a linguagem, que culmina em criações linguísticas amplamente empregadas em seus trabalhos artísticos, e que constituem componentes relevantes de um projeto estético baseado, sobretudo, em pintura e escritura. Na obra de Xul Solar, os jogos poéticos entre texto e imagem constituem um modo estimulante de conformar sentidos:

Trato que minhas pinturas - nos diz Xul Solar - tenham, além dos valores plásticos, símbolos efetivos que lhes dêem caráter de escritura com a

\footnotetext{
${ }^{4}$ SARLO. Una modernidad periférica: Buenos Aires 1920 y 1930, p. 15.
} 
finalidade de definir e situar os elementos de uma arte total e abstrata (...). Entendo que para estar em sua época o artista deve ser polifásico, quer dizer, não se enquadrar somente em uma cultura. Uma pintura egípcia ou budista me parece tão atual quanto uma de Picasso. ${ }^{5}$

A abordagem das implicações escriturais e plásticas da instauração do interrelacionamento entre texto e imagem na produção do artista segue, no entanto, ainda pouco explorada. Sob tal perspectiva, este estudo analisa o diálogo estabelecido entre as artes do visual e do verbal, a partir do processo de inserção da escritura na obra plástica de Xul Solar. Segundo uma leitura transdisciplinar de sua obra, a evolução do trabalho do artista é inquirida em seu percurso progressivo de imbricação entre pintura e escritura. Ao investigar as diversas nuances conformadas pelo contato entre texto e imagem, o que se objetiva é, sobretudo, teorizar a respeito da poética visual resultante do trabalho artístico desenvolvido enquanto escritura pictural. E dessa maneira, realizar uma apreciação das obras selecionadas, devidamente situadas em seu contexto de produção, no que concerne à plasticidade e à legibilidade destas, a partir da inserção, justaposição, ou fusão entre texto e imagem. Para tanto, foram selecionadas pinturas, em aquarela e têmpera, que se apresentam como obras representativas das distintas expressões interartes surgidas a partir da relação de aproximação entre texto e imagem.

A premente busca por uma arte compósita faz com que a produção pictórica de Xul Solar constitua uma trajetória criativa de confluências entre escritura e pintura. Nesse sentido, Xul Solar parece compreender que entre os atos de escrever e de pintar existe um componente partilhado - o traço - produto do gesto gráfico, do ato de marcar um suporte, de produzir uma impressão, ${ }^{6}$ que, como paradigma e processo, uma vez que abarca tanto a perspectiva de protocolo experimental, quanto a dimensão gnoseológica de um modo de apreensão do mundo, lega-nos, como resultado material, signos visuais e verbais. $\mathrm{O}$ exame do conjunto da obra do artista nos permitiu verificar que o percurso de inserção da escritura na pintura de Xul Solar consiste em uma gradação, em que textos e imagens se combinam em uma mescla que, ao longo do processo evolutivo de criação, adquire diversas configurações, até alcançar o indissociável. Diante disso, os trabalhos pictóricos do artista puderam ser elencados em quatro categorias fundamentais, a saber: a pintura legendada, a pintura verbal, as primeiras grafías, ditas herméticas, e, finalmente, as grafías plastiútiles ou pensinformas.

\footnotetext{
${ }^{5}$ XUL SOLAR. Xul Solar, pintor de símbolos efectivos, p. 81, tradução nossa.

${ }^{6}$ DIDI-HUBERMAN. L'empreinte, p. 26.
} 
Toda a nossa experiência da pintura comporta um considerável estrato verbal, já que os quadros jamais são vistos sozinhos, como uma visão pura, mas, como observa Michel Butor, encontram-se imersos em um universo de comentários de crítica de arte, catálogos, resenhas, convites, etc. ${ }^{7}$ Diante disso, constatamos que as pinturas são socialmente determinadas por discursos verbais externos às obras, como aqueles que conformam os títulos atribuídos aos trabalhos artísticos. Essa relação entre as obras de arte e os enunciados verbais se intensifica, especialmente, quando as palavras adentram a pintura. Apesar de a datação dos quadros de Xul Solar não ser estritamente precisa, podemos demarcar que a incorporação da escritura em sua pintura tem início aproximadamente entre os anos de 1916 e 1918, a partir do transporte dos títulos dos trabalhos do exterior para a interioridade das obras. Com a inserção dos títulos próximos ao espaço de composição pictórico, estes passam a constituir parte inerente às criações e a contribuir mais diretamente para a produção de sentido dos trabalhos.

Como obra emblemática do período, temos El sol herido (1918) [O sol ferido], cuja representação tematiza o sol como uma divindade que trava um combate com um guerreiro indígena, em uma possível alusão às narrativas mesoamericanas da era pré-colombiana, como o mito fundador El fechador del Sol [O arqueiro do Sol], da cultura mixteca. Segundo a referida narrativa mitológica, na busca pela conquista da região em que se estabeleceria a população mixteca, o destemido guerreiro Dzahuindanda enfrenta o senhor das terras, o Sol, em uma batalha em que o astro rei se fere e o indígena sai vitorioso. Na leitura intersemiótica que realiza, ao transpor o texto mitológico para a pintura, Xul Solar concede ênfase ao Sol, símbolo universal convertido em signo pessoal, que se torna constante em sua iconografia, figurado em primeiro plano na parte superior do quadro, em uma representação do conflito que privilegia a perspectiva do vencido.

Na pintura dos códices, segundo observa Santos Zuzunegui, os mixtecas criaram técnicas de registro gráfico que, ao fazerem o verbal e o visual convergirem em figurações simbólicas, encenam um duplo nível de leitura para as obras. ${ }^{8}$ No quadro de Xul Solar, em que temos a representação imagética conjugada a um texto, existe uma referenciação entre código visual e verbal, que se manifesta, sob outra ordem, na esfera da recepção, pois quem observa a pintura, lê o texto, e aquele que observa o texto, busca ler a pintura. Se no quadro do artista o processamento dos dois códigos não se dá de modo concomitante, como na

\footnotetext{
${ }^{7}$ BUTOR. Les mots dans la peinture, p. 8.

${ }^{8}$ ZUZUNEGUI. Pensar la imagen, p. 104.
} 
pintura/escritura mixteca, mas de maneira subsequente, em outra temporalidade, ainda sim, os dois códigos são lidos de modo intrinsecamente relacionado.

A obra, concretizada por meio da justaposição entre imagem e texto, com a primazia da primeira, conforma ainda um tipo de transposição intersemiótica, que parte da imagem à escrita e ocorre no interior de uma única obra de arte. Isso ocorre, segundo Leo Hoek, "quando o texto - título inscrito sobre a moldura do quadro, legenda da imagem, palavras grifadas na margem - tem por função nomear e identificar uma imagem: função esta que resulta em uma obra multimedial”. ${ }^{9}$ A obra multimedial, também denominada de multimídia, segundo a classificação posteriormente conferida por Claus Clüver, esboça um tipo de relação intersemiótica/intermidiática, na qual temos um todo texto textual composto por textos de diferentes sistemas de significação, completos de sentido em si, e, portanto, passíveis de serem isolados sem que, no entanto, percam a coerência. ${ }^{10}$

A obra $E l$ sol herido consiste em uma pintura em aquarela sobre papel, montada sobre cartão, em um encaixe de suportes. Nesse espaço híbrido, que se insinua como pintura nos traços delineados e também dá a ver o suporte e sua exterioridade, irrompe a inserção de uma inscrição textual. É como se fosse delimitado um núcleo, onde estão situadas as imagens, e a obra se diluísse em relação à periferia do quadro, onde surge o texto. Redigida em caligrafia tímida e bem cuidada, a inscrição é composta pelo título da obra em inglês (The wounded sun) e em francês (Le soleil blessé), em uma mostra do interesse linguístico do pintor e de seu desejo de dialogar com diferentes culturas, juntamente com a assinatura do artista. Em obras como essa, as imagens precedem os textos no esquema de representação e o escritural, como legenda, existe em relação direta com a cena pintada, pois pressupõe o imagético, conformando uma espécie de pintura legendada.

A localização periférica, a objetividade e o pequeno tamanho da fonte das inscrições são características que conferem o atributo de legenda à escritura, o que, entretanto, não diminui a abrangência dos textos veiculados. Podemos perceber que, se na esfera da produção o texto se alinha à imagem e se origina a partir dela, na perspectiva da recepção, os títulos representam, por sua vez, certa ancoragem de sentido para o entendimento das imagens. A leitura dos títulos dispostos diretamente sobre a obra gera a afirmação destes, tendo em vista que condiciona ainda mais o receptor a interpretar a pintura consoante ao elemento verbal do que quando há uma textualidade externa ao objeto artístico. Nesse aspecto, a inserção textual

\footnotetext{
${ }^{9}$ HOEK. A transposição intersemiótica: por uma classificação pragmática, p. 171.

${ }^{10}$ CLÜVER. Inter Textus/Inter Artes/Inter Media, p. 19.
} 
corresponde a um mecanismo de endosso do conteúdo comunicado, que se apresenta, por conseguinte, duplamente expresso na obra, na representação imagética e no enunciado da legenda bilíngue. Isso somente ocorre, uma vez que os títulos interpostos junto às obras de Xul Solar mantêm, de modo geral, uma evidente conexão com a cena pintada.

Posteriormente, com o adensamento do projeto de reinvenção linguística aventado por Xul Solar, a aproximação entre distintos fazeres criativos emerge como um movimento consequente e natural. Signos, palavras e pequenos textos alcançam, por conseguinte, o interior das pinturas, inserindo-se completamente na superfície pictórica, como constituintes da representação, harmonizados com o arranjo de formas do quadro. Desse modo, texto e imagem se coadunam para gerar os devidos efeitos de sentido a serem suscitados pela composição pictural. Mario Gradowczyk, grande estudioso da obra de Xul Solar, denomina a tal elaboração pictural, que introduz textos curtos redigidos em neocriollo rudimentar, relativamente legível, aos quadros, de pintura verbal. ${ }^{11}$ Nana Watzin (1923), obra que compõe em pintura o mito cosmogônico asteca de criação do sol e da lua, é representativa desse modo pictural. Na pintura verbal, mescla heterogênea de signos e figuras, temos uma associação de elementos de sistemas semióticos diversos, que são discerníveis ao olhar do receptor, pois não há imbricação, mas uma bem elaborada concatenação entre sistemas de significação.

Ao adentrar a superfície pictórica, a escritura é valorizada em seu caráter expressivo e visual, na qualidade de letrismo ou grafismo, combinando-se às figurações pintadas. A exemplo de Nana Watzin, nas pinturas verbais realizadas no período, temos, portanto, uma expressão mais acentuada da articulação entre verbal e icônico do que na pintura legendada. As palavras, signos e expressões presentes na pintura constituem fragmentos indiciais, potências de significação, ou ainda “ideogramas”, ${ }^{12}$ no dizer de Alfredo Rubione, pois, na qualidade de signos linguísticos cunhados na imagem, exigem que o receptor descubra as pistas neles abrigadas e depreenda sentidos. É preciso relacionar esses vestígios escriturais entre si, bem como também às figurações imagéticas do quadro, para avançar na busca pelas correlações de sentido entre os elementos da pintura, que geram a elaboração do significado do quadro. Tensionado entre textos e imagens, que partilham o mesmo espaço, integrados em um único conjunto, o receptor é incitado e tem de lidar com dois códigos na busca pela construção de sentido da obra.

\footnotetext{
${ }^{11}$ GRADOWCZYK. Alejandro Xul Solar, p. 50.

${ }^{12}$ RUBIONE. Xul Solar: utopia y vanguardia, p. 39.
} 
Na cena ritual retratada em Nana Watzin, a escritura, enquanto consubstanciadora de aspirações e votos cerimoniais, tanto se refere às figuras pintadas, enaltecendo e referendando-lhes o sentido, quanto se apresenta como objeto de culto, em seu caráter de significativo personagem materializado pelo rito. Estruturada em enunciados breves e fragmentos textuais distribuídos pelo quadro, a escritura, fabulada a partir da mescla de diferentes línguas, é composta por letras, signos e palavras em espanhol, em português e no idioma asteca nahuatl, constituintes do novo idioma. O texto se espalha pelo suporte e envolve as figuras representadas, nomeando-as, operando como saudações ao sagrado e gerando alusões a elementos diversos. Algumas deidades, como Xolotl e Tlazolteoltl, que não se encontram diretamente representadas na obra por meio de figurações, são invocadas a compor a pintura, por meio das inscrições dos nomes dos referidos deuses na superfície pictural, o que ressalta a atuação essencial da escritura na elaboração da cena.

No desejo de recuperar referências que permeiam as origens da cultura latinoamericana e, a partir delas, instaurar uma nova arte, Xul Solar promove, em Nana Watzin, uma releitura do mito asteca, por meio de uma representação de características modernas, com traços cubistas e uso expressivo da cor. $\mathrm{O}$ artista consegue produzir a condensação de todo um relato, a partir da retratação de uma cena ritualística, que abrange os acontecimentos envolvidos na narrativa. No quadro, conforme o mito, temos a representação da cena de ato sacrificial na fogueira, que converte Nanauatzin ou Nanahuatzin, um deus pobre e nazarento, mas muito corajoso, no quinto sol da concepção cíclica de tempo nahua. O deus Tecuciztécatl - que, segundo a narrativa, após se acovardar, resolve imitá-lo e se transforma em lua, astro de menor brilho - é também figurado na obra, juntamente com outros elementos imagéticos e verbais, que concorrem para que o trabalho se construa como uma pintura narrativa.

Na elaboração da história representada, as inserções textuais endossam o imagético e injetam conteúdos que ganham sentido na relação que estabelecem com as figuras e formas esboçadas. Desse modo, ao adentrar o quadro, a escritura impacta as figurações representadas e contribui para a concatenação de sentidos no trabalho plástico, que, na dinâmica entre texto e imagem, constrói-se como narrativa imagético-verbal.

A partir de 1935, Xul Solar realiza os quadros da série Todo Escrito [Tudo Escrito], que constituem a primeira produção de grafías do artista. Diante de tais pinturas, o receptor não mais oscila entre as imagens e os elementos verbais, pois a sua atenção se detém nos traços, signos e intervalos que delineiam a plasticidade de um grafar bastante pessoal. Nos quadros desse ciclo, como Grafía Antica (1939), a escritura, tornada imagem, expande-se pelo espaço pictórico e emerge como o motivo focal da representação, ao conformar grafismos que 
salientam a interferência sofrida pelo espaço de representação, o gesto gráfico experimentado pelo artista. As grafias, surgidas da intersecção entre grafito e grafema, têm a sua materialidade visual salientada e, como resquícios visuais de um contato, fazem com que a atuação do artista sobre a matéria persista no tempo. Nesse sentido, são indicativas de um percurso de impressão, perduram como vestígios do ato de marcar, corromper um suporte. A escritura surge, portanto, para além de sua instrumentalidade, como o registro figural de um processo de marcação, tendo em vista que, como assevera Barthes, sua verdade reside na “mão que apóia, traça e dirige, isto é, no corpo que vibra (que goza)”. ${ }^{13}$ Nessas pinturas, emaranhados de grafismos se superpõem e dissolvem, em camadas e tramas textuais, construídas por meio das transparências e veladuras da técnica de têmpera sobre papel. Com essas obras, Xul Solar confere um novo patamar para o diálogo entre texto e imagem instituído em sua produção artística, que se torna ainda mais vívido, tendo em vista que ele promove a conjunção entre os gestos de escrever e de pintar na produção de tais trabalhos.

Fundados na dualidade verbal/icônico, os quadros da série sugerem grafismos elaborados de acordo com algum sistema simplificado de linguagem. Como nos informa Patrícia Artundo, Xul Solar, inclusive, dispunha de manuais de taquigrafia segundo as metodologias de Francisco P. Martí e de Isaac Pitman. ${ }^{14}$ Como escrituras de artista, as grafías de Xul Solar configuram, entretanto, inscrições particularizadas, de significação não partilhada, visíveis, porém não legíveis, uma vez que não possuem uma chave léxica que opere como um guia para a decifração e interpretação de seu conteúdo. Tal experimentação gráfica convertida em código fechado faz sobrevir o significante em seu estrato visual, sugerindo-nos uma mística da escritura, em que a necessidade de comunicar cede ao desejo de compor um enigma por meio da linguagem. Ao não cooptar com a concepção de que todo código dever pressupor uma norma e, por conseguinte, uma legibilidade direcionada, Xul Solar estimula o receptor das obras a romper com o condicionamento de buscar a convenção que rege o signo, impelindo-o a "trabalhar" os textos segundo outras premissas. Isso configura, em um primeiro contato, um processo desorientador, mas que se mostra, por outra parte, bastante instigante:

Diante de um alfabeto completamente estranho meu olhar é desconcertado, eu reconheço que ele consiste em uma inscrição devido ao sistema formado por seus signos, mas ela constitui como uma zona de perdição, e eu tanto

\footnotetext{
${ }^{13}$ BARTHES. O óbvio e o obtuso: ensaios críticos III, p. 140.

${ }^{14}$ ARTUNDO. Papéis de trabalho. Introdução a uma exposição retrospectiva de Xul Solar, p. 28.
} 
teria esse sentimento de perdição como seria melhor advertido sobre a pluralidade das escrituras. ${ }^{15}$

A ilegibilidade dos conteúdos cifrados no escrito soa bastante provocativa, já que vai de encontro à celebrada função comunicativa da linguagem, considerada pelos linguistas como de caráter fundamental. A escritura visível/ilegível, de Xul Solar, impõe uma fratura na linguagem, ao desafiar a lógica interacional, que supõe a instituição de um código referencial a ser trilhado como labirinto e, em seguida, o alcance da decifração desse mesmo labirinto. Diante da ausência de uma apreensão imediata de significados no contato com a escritura, o que se ressalta é uma característica intrínseca a todas as escrituras: a inexistência de um sentido imanente e fixo, de uma interpretação una, correta e definitiva a ser depreendida dos textos. Nessa perspectiva, como afirma Derrida, "a ausência de significado transcendental amplia indefinidamente o campo e o jogo da significação”. ${ }^{16}$

A obra Grafía Antica, como nos sugere seu título, alude-nos a uma escritura anterior, tendo em vista que a palavra antica, do latim antīcus/antīquus, refere-se àquilo que "existe previamente”, que é “antigo”. Em um recuo no tempo, ao evocar formas primitivas de marcação, como as proto-escritas, os grafismos presentes no quadro parecem sugerir um retorno às origens da escrita,ao reportar-nos às inscrições primevas traçadas pela mão do homem, gravadas na argila e na rocha, pintadas nas paredes das cavernas. Em contraposição às teorias que asseveram que a linguagem oral seria a base fundadora da escrita, a partir da transcrição da fala, emergem estudos recentes que argumentam em favor de uma origem icônica da escrita. Xul Solar parece corroborar tal proposição, ao compor a representação de grafismos que constituem marcas e rastros de um processo escritural, singular e impenetrável, suportado por seu caráter estético.

Da remissão aos grafismos rudimentares, efetuados no limiar entre pintura e escritura, sobrevém ainda a evocação da singularidade do homem, enquanto animal criador de códigos, ser de linguagem sígnica, homo symbolicus. A capacidade cognitiva de efetivamente empregar símbolos, produzir pensamento abstrato, que sabemos estar diretamente implicada na transformação do homem primitivo em sapiens, constitui o que, indubitavelmente, inaugurou o que somos hoje, em termos de espécie e civilização. Entre a pincelada e a letra, existe o traço como um elemento primordialmente comum, gerado pelo gesto gráfico, do qual nos fazemos artífices, como mediadores simbólicos que somos, e que a cada vez que é

\footnotetext{
${ }^{15}$ BUTOR. Les mots dans la peinture, p. 161, tradução nossa.

${ }^{16}$ DERRIDA. A escritura e a diferença, p. 410.
} 
repetido, vincula-nos a essa origem, que prevê que a atividade simbólica é biologicamente inerente à condição humana. Nesse aspecto, é pertinente salientar que as artes de escrever e de pintar se encontram intrinsecamente relacionadas, uma vez que convergem em uma mesma condição de origem, tendo em vista que compreendem atividades somente passíveis de serem realizadas pelo homem a partir da emergência da habilidade mental de desenvolver pensamento abstrato. Xul Solar aproxima tais artes que, por princípio, primam pela impressão em um dado suporte, a partir de suas experimentações em busca de uma linguagem plásticoescritural que proporcionasse novas possibilidades de estabelecer significados.

A primeira série de grafías parece constituir um estudo para as grafias plastiútiles, obras realizadas a partir do final da década de 1950, que constituem o auge do processo de imbricação entre pintura e escritura instaurado no percurso artístico de Xul Solar. A suposta prevalência icônica das representações, que sugerem pinturas abstratas ou o exercício de um grafismo livre, dissimula o arcabouço simbólico, o conteúdo verbal, subjacente nessas pinturas. Nas obras, constrói-se uma escritura de destacada plasticidade, por meio dos signos representados, que conformam um texto, cuja significação atravessa e ultrapassa o quadro, ao fundar-se a partir de um novo código expressivo, que inscreve uma gramática visual própria. O artista concebeu suas "formas pensamento" como a integração de textos, de sua autoria ou apropriações, com as formas geométricas ou pictóricas que os representariam, visando a promover uma nova comunicação visual.

Xul Solar experimentou e perseguiu incessantemente os mecanismos de uma criação artística que produzisse a correspondência entre escritura e pintura, para somente alcançá-la ao final da vida, com a invenção de complexos sistemas de notações, segundo os quais seus quadros eram elaborados. Para tanto, desenvolveu diversos alfabetos silábico-morfológicos, cujos signos, ao se combinarem, geravam uma singular escritura por meio da construção pictural dos trabalhos. Na produção dessas pinturas, Xul Solar elegia um texto a ser traduzido para o mecanismo de codificação fabulado por ele e, a seguir, transportava a estruturação gráfica resultante desse processo tradutório para superfície do quadro, concedendo-lhe tratamento artístico. As representações eram elaboradas pelo artista por meio da concatenação de grafismos pertencentes a um ou mais sistemas de grafías plastiútiles. A partir dessa técnica de pintura/escritura, constituía-se uma representação pictórica de simbolismo velado que expõe um texto cifrado nas formas e cores da pintura.

Nas obras, o enunciado textual, anteriormente presente na pintura verbal de Xul Solar, torna-se imbricado com o estrato visual do significante, intensamente explorado nas primeiras grafías, ditas herméticas. Os quadros recebiam ainda inscrições, que traduzem o enunciado 
verbal codificado nas pinturas para a língua neocriollo. Esses textos se encontram inseridos, geralmente, na parte inferior das obras, como na primeira nuance do processo de aproximação entre pintura e escritura, a pintura legendada. Diante disso, como assevera Mario Gradowczyk, podemos concluir que tais obras constituem uma espécie de somatória do que já realizara Xul Solar no decorrer de sua produção. ${ }^{17}$

Dentre algumas das pinturas de pensiformas mais conhecidas, temos a série de trabalhos criados a partir do adágio "Pax, Worke, Love”. Com a intervenção de Xul Solar, a estrutura originalmente binária do dito, que embalou o movimento beatnik e a geração hippie, é convertida em triádica, a partir da interposição da palavra trabalho - compreendida como esforço laboral - ao aforismo. Nas obras, o título referencia o texto representado na pintura das grafias plastiútiles, "Paz, Trabalho e Amor", por meio dos signos conformados no referido texto e artisticamente elaborados. Xul Solar costumava representar um mesmo tema ou texto em várias pinturas, concebidas segundo diferentes sistemas gráficos de linguagem, como no caso do referido aforismo, que originou quadros feitos a partir de alfabetos de grafias como os sistemas cursivo, silábico e vegetal. Se a repetição de um enunciado efetuada a partir de alfabetos diversos gerava a variação formal das representações, por meio de distintas sintaxes textuais, usos de luz e cores, composições de formas, e etc., determinava, por outra parte, um atrelamento semântico entre os distintos quadros provindos de um mesmo texto.

Nas grafías plastiútiles, assim como nas primeiras grafias de codificação fechada, temos trabalhos que se constituem a partir da imbricação entre sistemas semióticos, uma vez que pintura e escritura coincidem, tornando-se indissociáveis, de modo a compor signos e grafismos de proeminente plasticidade. Em ambas a série de pinturas surge um mecanismo de construção pictural que se conforma, antes, como poesia visual. Conforme afirma Leo Hoek, a escritura na poesia visual “é encarada como imagem: o texto que é normalmente instrumento de codificação linguística torna-se [também], aqui, objeto de outro tipo de codificação: a icônica”. ${ }^{18}$ As pinturas de pensiformas diferenciam-se, no entanto, das primeiras grafias, pois estabelecem um estimulante jogo expressivo com o significante, sem, contudo, privarem-se de conservar um significado inerente às formas representadas. Em outros termos, as pensiformas se alinham ao conceito de poesia visual, uma vez que se concretizam a partir de uma constituição artística sincrética, intersemiótica, estabelecida a partir de uma estrutura formal que faz texto e imagem convergirem em uma escritura pictural.

\footnotetext{
${ }^{17}$ GRADOWCZYK. Alejandro Xul Solar, p. 205.

${ }^{18}$ HOEK. A transposição intersemiótica: por uma classificação pragmática, p. 185.
} 
No percurso analítico traçado, buscamos demonstrar como a produção pictórica de Xul Solar conforma um continuum de aproximação entre as artes do texto e da imagem. Acompanhamos o surgimento de uma escritura incipiente, espécie de legenda do quadro que, a seguir, avança para a superfície pictural e converte o trabalho em pintura verbal. Nos dois primeiros momentos criativos, as inscrições eram empregadas como endosso e esclarecimento da imagem pintada, referendando-lhe os conteúdos. As pinturas verbais também traziam à cena, por meio da escritura, simbologias com o valor de figuração, assim como fomentavam a concretização da estrutura narrativa dos quadros. Posteriormente, com as primeiras grafías, que valorizam a iconicidade da escritura, signos e grafismos, ao se tornarem imagens, como foco de representação, constituem um modo de poesia visual. Emerge uma textualidade pictórica de código fechado e teor enigmático, que nos alude ao gesto inaugural da escrita, compreendido não como o registro de uma fala, mas o traço operado pela mão do homem. Com as pensiformas, enfim, temos a criação de uma técnica de pintar escrevendo ou escrever pintando, que reúne proporcionalmente iconicidade e simbolicidade, imbricando os distintos sistemas semióticos na feitura de uma poesia visual, que se faz uma original escritura pictural.

Na trajetória artística que realiza, movido pela incessante procura por um mecanismo de pintura/escritura, que produzisse uma espécie de metalinguagem plástica, uma poética do traço, o artista concebe uma diversificada produção pictórica. Percebemos que, após transitar entre a prevalência do caráter linguístico/verbal do texto, das pinturas legendada e verbal, e a supremacia da iconicidade do escrito, das primeiras grafias, o artista opta por uma mediação e direciona a sua produção pictórica final, as pensiformas, a uma posição dita intermediária, que conjuga escritura e pintura, de maneira equilibrada. Ao reunir o verbal e o visual, o poético e o plástico, em uma arte de comunicação, Xul Solar alcança, finalmente, a criação de imagens artísticas que se fazem um modo de escritura pictural, e que podem ser compreendidas como uma poética do “texto em imagem”.

\section{RESUMEN}

Este estudio investiga el diálogo que se establece entre las artes del texto y de la imagen, desde el proceso progresivo de inserción de la escritura en la obra pictórica del artista argentino Alejandro Xul Solar (1887-1963).

\section{Palabras Clave}

Escritura, pintura, poesía visual, estudios intersemióticos 


\section{REFERÊNCIAS}

ARTUNDO, Patricia. Papéis de trabalho. Introdução a uma exposição retrospectiva de Xul Solar. In: MUSEO DEL ARTE LATINOAMERICANO; PINACOTECA DO ESTADO DE SÃO PAULO. Xul Solar: visões e revelações. Buenos Aires/ São Paulo: MALBA/ Pinacoteca de São Paulo, 2005, p. 21-33. Catálogo de exposição.

BARTHES, Roland. O óbvio e o obtuso: ensaios críticos III. Trad. Léa Novaes. Rio de Janeiro: Nova Fronteira, 1990.

BUTOR, Michel. Les mots dans la peinture. Genebra: Skira, 1969.

CLÜVER, Claus. Inter Textus / Inter Artes / Inter Media. Aletria, Belo Horizonte, n. 14, p.1141, jul.-dez. 2006.

DERRIDA, Jacques. A escritura e a diferença. Trad. Maria Beatriz da Silva, Pedro Lopes e Pérola de Carvalho. São Paulo: Perspectiva, 2009.

DIDI-HUBERMAN, Georges. L'empreinte. Paris: Édition du Centre Georges Pompidou, 1997.

FOUCAULT, Michel. Isto não é um cachimbo. Trad. Jorge Coli. São Paulo: Paz e Terra, 1989.

GRADOWCZYK, Mario. Alejandro Xul Solar. Buenos Aires: Ediciones Alba; Fundação Bunge y Born, 1994.

HOEK, Leo. A transposição intersemiótica: por uma classificação pragmática. In: ARBEX, Márcia (Org.). Poéticas do visível: ensaios sobre escrita e imagem. Belo Horizonte: Programa de Pós-Graduação em Letras: Estudos Literários, Universidade Federal de Minas Gerais, 2006.

RUBIONE, Alfredo. Xul Solar: utopia y vanguardia. Punto de Vista, Buenos Aires, n. 29, p. 37-39, abr./jul. 1987.

SARLO, Beatriz. Una modernidad periférica: Buenos Aires 1920 y 1930. Buenos Aires: Ediciones Nueva Visión, 1988.

XUL SOLAR, Alejandro. Autómatas en la história chica. In: Alejandro Xul Solar.

Entrevistas, artículos y textos inéditos. Org. e prólogo de Patricia M. Artundo. Buenos Aires: Corregidor, 2005. p. 132-145.

XUL SOLAR, Alejandro. El sol herido. 1918. Aquarela sobre papel, 25 x $21 \mathrm{~cm}$. In: GRADOWCZYK, Mario Horacio. Alejandro Xul Solar. Buenos Aires: Ediciones Alba; Fundação Bunge y Born, 1994a. p. 36.

XUL SOLAR, Alejandro. Grafia Antica. 1939. Têmpera sobre papel, 35 x 55 cm. In: GRADOWCZYK, Mario Horacio. Alejandro Xul Solar. Buenos Aires: Ediciones Alba; Fundação Bunge y Born, 1994b. p. 208.

XUL SOLAR, Alejandro. Nana Watzin. 1923. Têmpera sobre papel, 23,5 x 31,5 cm. In: GRADOWCZYK, Mario Horacio. Alejandro Xul Solar. Buenos Aires: Ediciones Alba; Fundação Bunge y Born, 1994c. p. 85.

XUL SOLAR, Alejandro. Pax, Worke, Love. 1961. Têmpera sobre papel, 16, 4 x 22 cm. (Sistema cursivo). In: MUSEO DEL ARTE LATINOAMERICANO; PINACOTECA DO ESTADO DE SÃO PAULO. Xul Solar: Visões e Revelações. Buenos Aires/ São Paulo: MALBA/Pinacoteca de São Paulo, 2005a, p. 151. Catálogo de exposição. 
XUL SOLAR, Alejandro. Xul Solar, pintor de símbolos efectivos. In:

Alejandro Xul

Solar. Entrevistas, artículos y textos inéditos. Org. e pról. de Patrícia M. Artundo. Buenos Aires: Corregidor, 2005b, p. 80-87. Entrevista concedida a Carlos A. Foglia.

ZUZUNEGUI, Santos. Pensar la imagen. 6. ed. Madrid: Ediciones Cátedra, 2005. 


\section{AnEXOS}

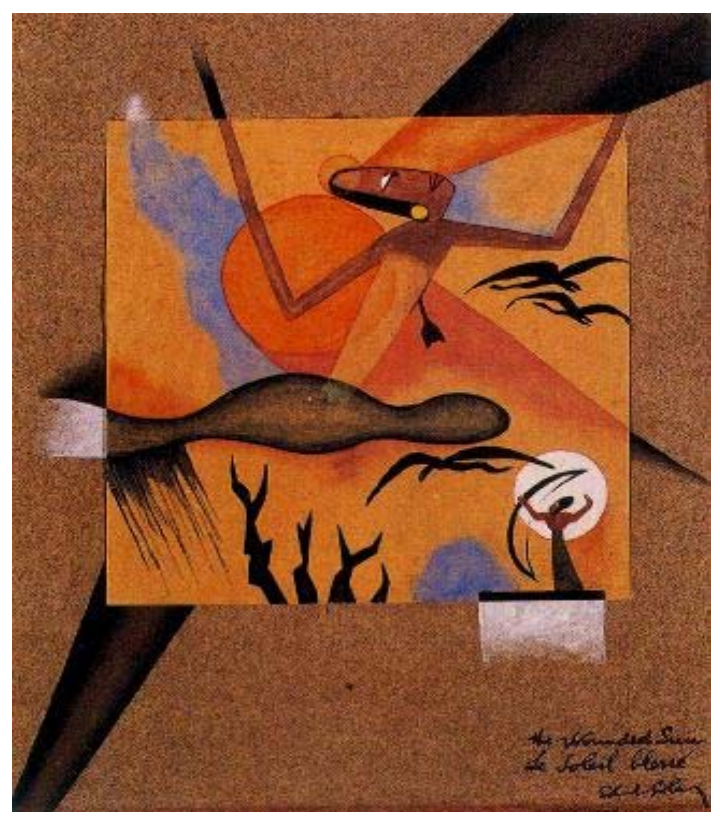

FIG. 1: XUL SOLAR. El sol herido. 1918. Aquarela sobre papel. 25 x $21 \mathrm{~cm}$. Fonte: GRADOWCZYK. Alejandro Xul Solar, p. 36.

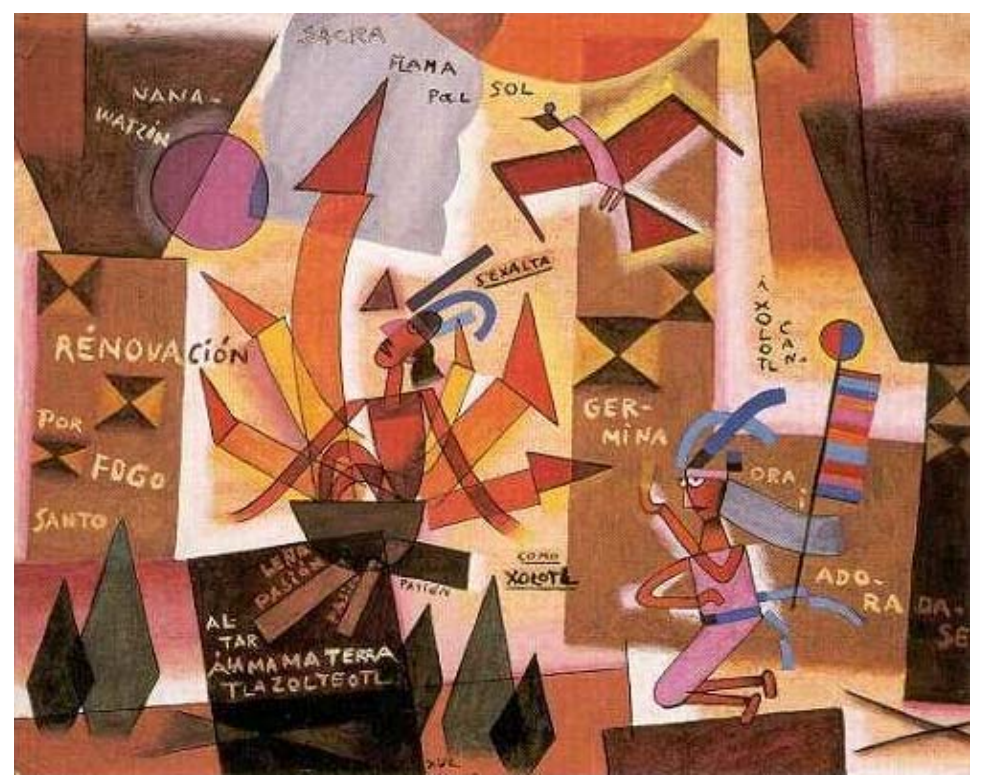

FIG. 2: XUL SOLAR. Nana Watzin. 1923. Têmpera sobre papel. 23,5 x 31,5 cm. Fonte: GRADOWCZYK. Alejandro Xul Solar, p. 85. 


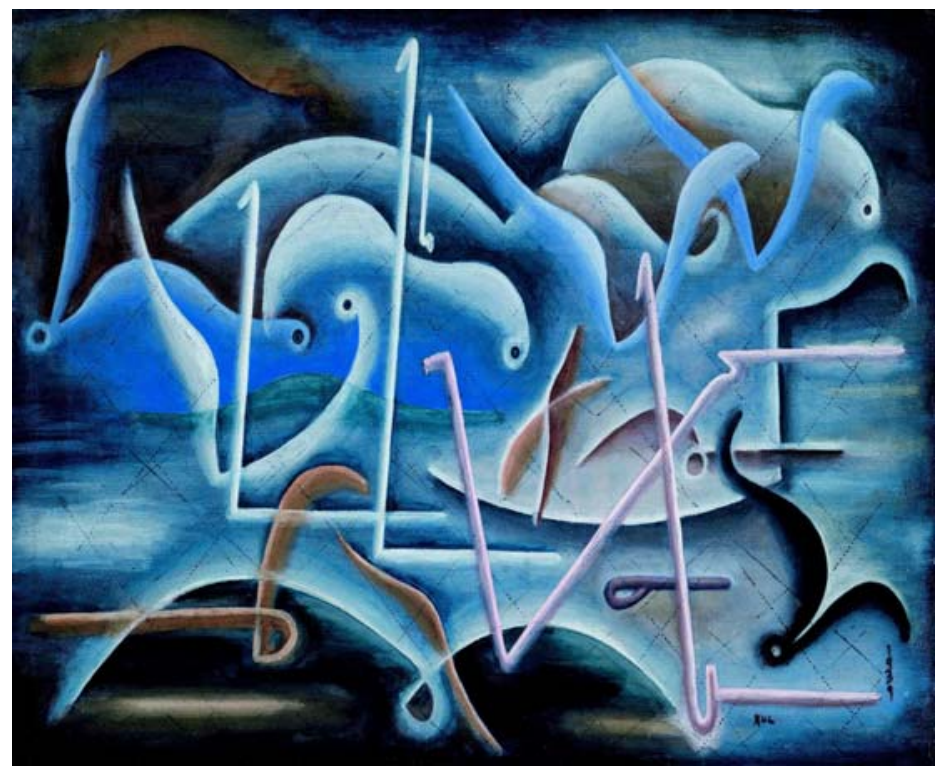

FIG. 3: XUL SOLAR. Grafia Antica. 1939. Têmpera sobre papel. 35 x 55 cm. Fonte: GRADOWCZYK. Alejandro Xul Solar, p. 208.

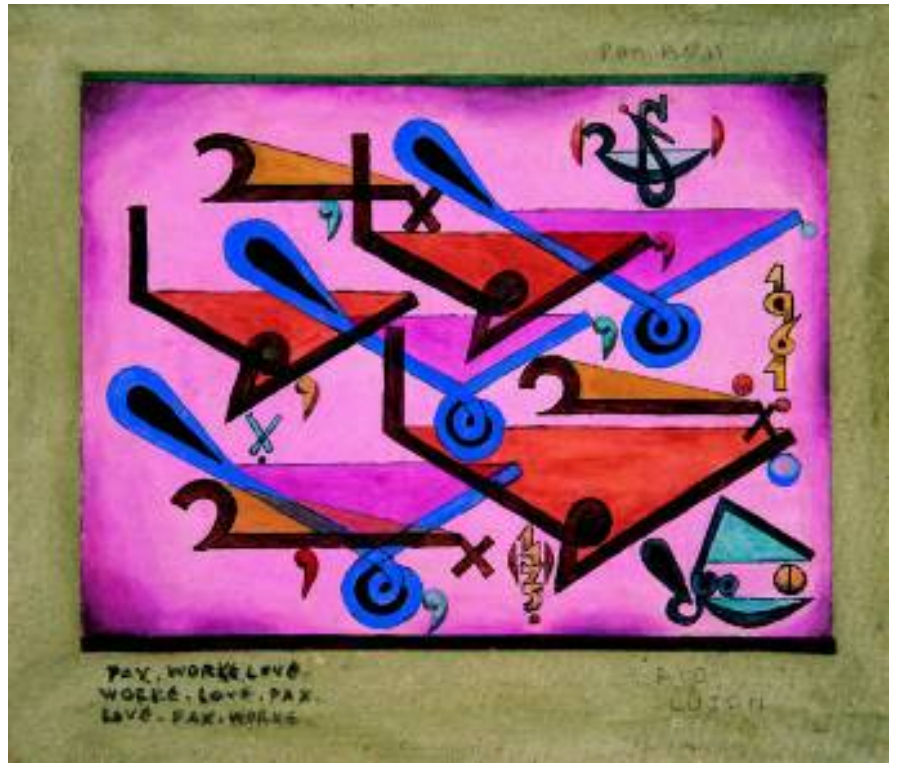

FIG. 4: XUL SOLAR. Pax, Worke, Love. 1961. Têmpera sobre papel. 16,4 x 22 cm. Sistema cursivo. Fonte: MUSEO DEL ARTE LATINOAMERICANO, PINACOTECA DO ESTADO DE SÃO PAULO. Xul Solar: visões e revelações, p. 151. Catálogo de exposição. 